DOI: https://doi.org/10.32838/2523-4803/70-5-10

УДК 342.951

Савченко О.Р.

кандидат економічних наук, доцент кафедри менеджменту,

Рівненський державний гуманітарний університет

\title{
Savchenko Olha
}

Rivne State Humanities University

\section{СИСТЕМНО-ФУНКЦОНАЛЬНА МОДЕЛЬ ПУБЛІЧНОГО АДМІНІСТРУВАННЯ РЕФОРМУВАННЯ ГАЛУЗІ ОХОРОНИ ЗДОРОВ'Я}

\begin{abstract}
Сучасна Україна перебуває в активному русі, який здійснюється шляхом розроблення та втілення реформ у різні галузі. Однією з головних реформ, від якої залежить демографічний, сочіальний та економічний потенціал суспільства, є реформа сфери охорони здоров'я. Відповідно до законодавства України, охорона здоров'я є одним із пріоритетних напрямів державної діяльності та має свої особливості. У статті здійснено загальний аналіз державної політики у сфері охорони здоров'я, який дав змогу здійснити ії обтрунтування з позииії системного та функиіонального підходів. Окреслено особливості, зміст та напрями адміністрування реформи галузі охорони здоров'я України, щзо потребує негайного розроблення організаційних, управлінських, політико-правових засад. Запропоновано схематичне відображення моделі системно-функціонального підходу до публічного адміністрування проиесу реформування галузі.
\end{abstract}

Ключові слова: державна політика, адміністрування, реформування, система охорони здоров'я, системно-функціональний аналіз.

Постановка проблеми. Сучасні реалії сфери охорони здоров'я, яка й без того має численні проблеми, такі як низький рівень фінансового та матеріального забезпечення, технічно відстала інфраструктура, недосконалий менеджмент, відсутність належної системи мотивації кадрів, високий рівень корупції у всіх сферах та ланках, характеризуються ще й появою загальносвітового незвіданого чинника, а саме пандемією коронавірусної інфекції. Старі й нові проблеми галузі, яка переживає реформування, загострюють потребу швидких та рішучих дій, спрямованих уже не лише на реалізацію визначеної стратегії розвитку медичної системи, але й на боротьбу за виживання населення загалом. Практика показала, що в цій боротьбі держава не спроможна самотужки впоратися з визначеною проблемою пандемії, отже, їй мають допомогти бізнес, громадські організації та свідомий підхід громадян. Оскільки реформування, як загальновідомо, - це процес оптимізації, що передбачає вибір найкращого варіанта 3 числа можливих альтернатив, або процес приведення системи в найкращій (оптимальний) стан, то актуальним є розгляд процесу реформування системи охорони здоров'я через системно-функціональний розподіл функцій та завдань між їх виконавцями та відповідальними.

Аналіз останніх досліджень і публікацій. Ми проаналізували роботи науковців, у яких започатковано вирішення проблеми організаційних заходів держави щодо забезпечення доступної та якісної медичної допомоги населенню. Так, принципи управління якістю медичних послуг досліджувалися такими вченими, як А.Б. Зіменковський, А.Н. Морозов, А.М. Нагорна, А.В. Степаненко, Ю.В. Фломін; дослідженню правових та управлінських аспектів медичної діяльності присвятили праці В.Б. Авер'янов, 3.С. Гладун, О.М. Голяченко, В.Б. Дейч, О.Л. Корольчук, А.Ф. Мельник, Я.Ф. Радиш, І.Я. Сенюта, В.Ю. Стеценко, С.Г. Стеценко, Я.Ю. Шегедин; питанням підвищення управлінської ролі органів місцевого самоврядування присвячує роботу А.В. Шипко; особливостям взаємодії управлінських органів у сфері охорони здоров'я, їх системності присвячують дослідження Г.В. Муляр, Я.Ф. Радиш та інші науковці.

Численні доробки вітчизняних науковців, що присвячені реформуванню сфери охорони здоров'я, особливо в сучасних умовах появи непередбачуваного чинника пандемії коронавірусної інфекції ще більше потребують подальшого теоретичного та практичного аспекту розвитку публічного адміністрування в контексті не лише нормативно-правового та організаційного забезпечення, але й наукового.

Формулювання цілей статті. На основі викладеного можна сформулювати завдання дослідження, яке полягає в розгляді загальних засад системно-функціонального розподілу публічного адміністрування реформи системи охорони здоров'я України щодо визначення іiї рівнів, суб'єктів та зв'язків, мети та завдань медичної реформи.

Виклад основного матеріалу. Конституція Української держави у ст. 3 визначає, що найвищою соціаль- 
ною цінністю є людина, іiї життя та здоров'я, а також безпека. Підходи до формування державної політики у сфері охорони здоров'я задекларовано в Конституції України (ст. ст. 43, 45, 46, 48-50) [1].

Відповідно до підходу колективу авторів [2], громадське здоров'я - це комплексна політична, економічна, соціальна й медична категорія, що інтегрує індивідуальне здоров'я громадян, обумовлене дією сукупності політичних, економічних, соціальних і біологічних чинників, визначає демографічний, соціальний, економічний потенціал суспільства, $є$ фактором національної безпеки та об’єктом соціальної політики держави.

Як зазначають О.О. Дорошенко та М.В. Шевченко [3, с. 148], кожна людина має природне невід'ємне та непорушне право на охорону здоров'я. Державні, громадські та інші організації, посадові особи зобов'язані забезпечувати пріоритетність охорони здоров'я у своїй діяльності. Задля забезпечення соціальних пріоритетів на доступному та якісному рівні необхідне впорядкування системи охорони здоров'я через ефективну політику публічного адміністрування.

Відповідно до підходу Я.Ю. Шегедин, сферу охорони здоров'я та відповідну державну політику доцільно розглядати системно й процесуально:

- системно як відкриту, динамічну, складну суспільну систему, яку утворюють комплекси (підсистеми) «різноманітних державних і недержавних органів і організацій, діяльність яких здійснюється на основі міжгалузевих відносин і спрямована на збереження, зміцнення і відновлення здоров'я населення»;

- процесуально в напрямах державно-управлінської діяльності, а саме державного будівництва, яке охоплює визначення й правове закріплення форми державного правління; політичного режиму; державнотериторіального устрою; основних цілей і функцій держави, їх пріоритетності; розподілу повноважень між гілками та вищими органами державної влади; стратегії розвитку держави; структури органів державної влади відповідно до функцій держави та ії стратегічних цілей; формування державної політики з різних галузевих напрямів діяльності держави; реалізації державної політики, яка передбачає виконання функцій державного управління (оперативне й тактичне управління) для досягнення визначених цілей держави в певний період їі історичного розвитку.

Згідно з визначенням ВООЗ, система охорони здоров'я - це сукупність усіх організацій, інститутів і ресурсів, головною метою яких є поліпшення здоров'я нації. Для функціонування системи охорони здоров'я необхідні кадрові ресурси, фінансові кошти, інформація, устаткування й матеріали, транспорт, комунікації, а також загальне керування й керівництво [5].

Відповідно до тлумачення Я.Ф. Радиш [6, с. 15], «державна система охорони здоров'я України є складною організаційною соціальною функціональною багаторівневою ієрархічною керованою системою, діяльність якої спрямована на раціональне використання наукового і соціально-економічного потенці- алу країни; комплексне динамічне спостереження за станом здоров'я людини і всього суспільства з метою збереження та розвитку фізіологічних і психологічних функцій; оптимальної працездатності та соціальної активності людини за максимальної біологічно можливої індивідуальної тривалості життя».

Публічне управління у галузі охорони здоров'я визначається державною політикою у сфері охорони громадського здоров'я, яка зорієнтована на забезпечення рівноправності кожної людини та окремих громад у доступі до медичного обслуговування [2].

Аналізуючи зміст управління сферою охорони здоров'я, Н.М. Ткачова визначила такі підходи [7, с. 85]:

- державне управління охороною здоров'я $є$ одночасно механізмом та формою реалізації управління суспільством;

- управлінський вплив обов'язково містить організаційний компонент у медичному закладі, який проявляється у спрямуванні та практичному здійсненні взаємодії людей і має два зрізи, а саме статичний (структурний) та динамічний (функціональний);

- існує поділ медичної сфери як загального інституту управління на певну суб' єктну структуру, що складається з органів державного управління та бізнесу;

- об'єктами державного управління сфери охорони здоров'я $є$ певні суспільні відносини, з одного боку, та відносини у самій організаційній системі, тобто відносини між різними органами держави, всередині та між самими лікувальними установами, з іншого боку.

3 огляду на вищенаведене, далі, не претендуючи на повний перелік елементів системи, на рис. 1 ми наводимо спрощену модель системно-функціонального розподілу публічного адміністрування реформи системи охорони здоров'я України.

Наведена модель не лише відображає чітке розмежування завдань i функцій між виконавцями реформи, але й демонструє структуру комунікацій між суб'єктами-учасниками реформи на основних рівнях та напрямах системи. Згідно 3 наведеною моделлю, можемо визначити іiі ключові складові елементи та характеристики.

1) До основних елементів відносимо керуючу (держава в особі іiі органів та установ основних гілок влади (законодавча - ВРУ, а також профільний парламентський Комітет 3 питань здоров'я нації, медичної допомоги та медичного страхування, до складу якого входять підкомітети з питань медичного страхування, охорони здоров'я, фармації та фармацевтичної діяльності, сучасних медичних технологій та розвитку трансплантології, забезпечення епідемічної безпеки, боротьби із ВІЛ/СНІД та іншими соціально небезпечними захворюваннями, медичної техніки та медичного страхування, оздоровлення та охорони материнства й дитинства, військової медицини, технічного регулювання та стандартизації у сфері охорони здоров'я, профілактики онкологічних захворювань та боротьби 3 ними; виконавча - КМУ, МО3, Національна служба здоров’я України (НСЗУ) та судова гілка, органи міс- 


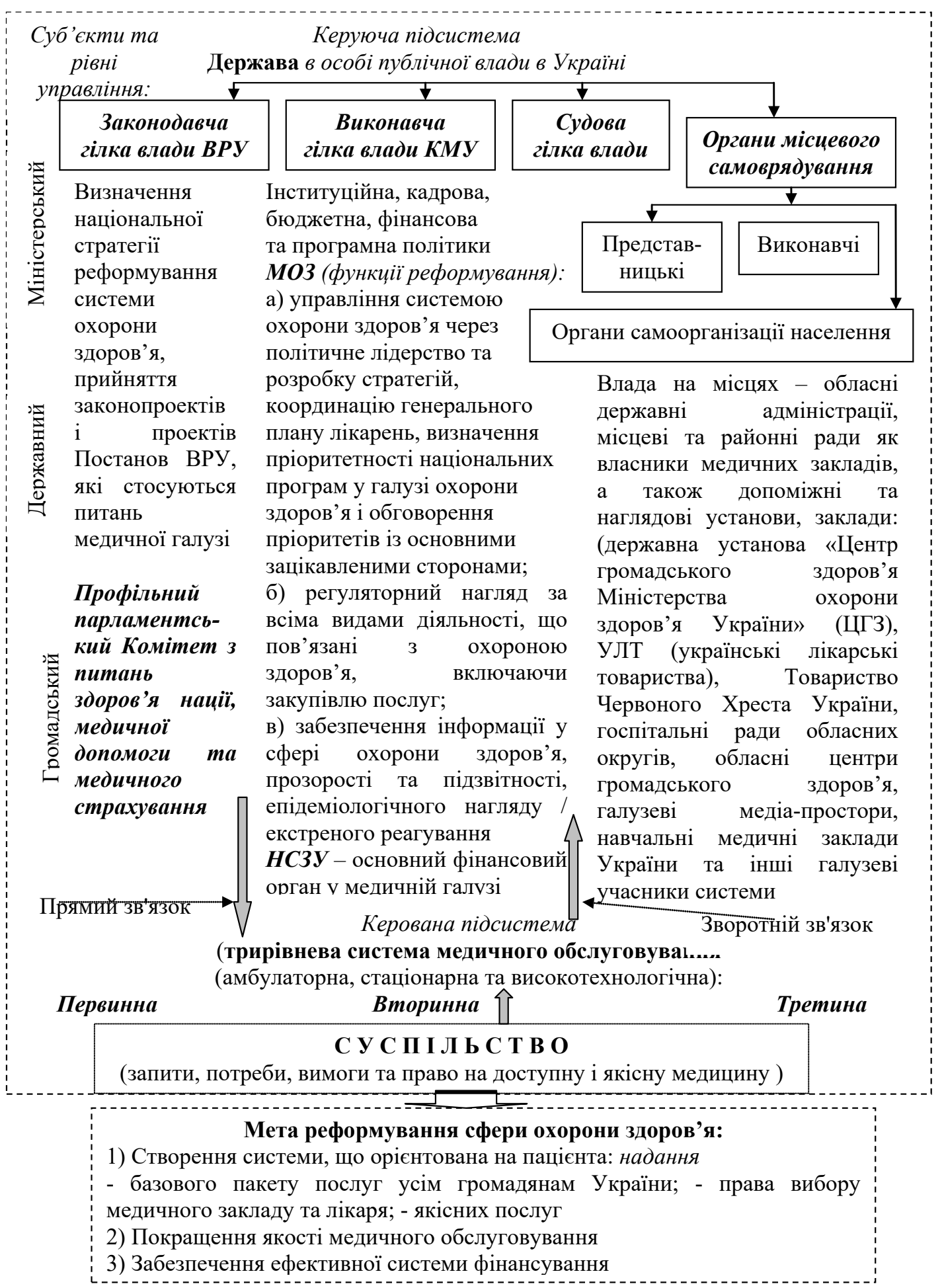

Рис. 1. Системно-функціональна модель адміністрування реформування системи охорони здоров'я України

Джерело: складено автором на основі джерела [8]

цевого самоврядування) на різних рівнях системи (міністерський, державний, громадський)) та керовану (медична сфера з усіма iї інфраструктурою, кадрами, технологіями та іншими складовими частинами, суспільство, а також, відповідно до вертикалі адміністрування, інші структурні одиниці) підсистеми.
2) Наявність прямого зв'язку зверху донизу, що в принципі відображає державну політику у сфері охорони здоров'я (завдання та цілі реформи, а також принципи, функції, механізми та методи адміністрування); зворотного зв'язку (від об'єкта управління (суспільства й самої медичної сфери) до суб'єкта управління (дер- 
жави)), що відображає потреби та запити суспільства або реакцію (задоволеності, зрозумілості) на прийняті управлінські рішення та вжиті заходи; інформаційнокомунікативного зв'язку (взаємодія органів виконавчої влади, місцевого самоврядування та інститутів громадянського суспільства під час вжиття заходів правового, організаційного, інституційного, кадрового, фінансового, інформаційного сприяння розвитку системи).

3) Система є складною та відкритою, має функціонувати, враховуючи дію міжнародних (політика ВОО3), політичних, економічних, соціальних, біологічних чинників; публічною, тобто відкритою та доступною для суспільства, а також через наявність громадського суб'єкта в системі адміністрування. Як зазначає О.Л. Корольчук, добре налагоджений інформаційно-комунікаційний зв'язок є можливим через технічні та технологічні засоби задля не лише покращення функціонування державної системи охорони здоров'я, але й підвищення рівня освіченості громадян щодо можливостей медичної галузі сьогодні, збільшення мотивації людей до піклування про власне здоров'я та ведення здорового способу життя, забезпечення відкритого діалогу влади й громади [9].
Актуальним є твердження Г.В. Муляр [10, с. 100] щодо того, що система управлінських та організаційних механізмів у сфері охорони здоров'я має діяти узгоджено між суб'єктами, цілісно та збалансовано на всіх рівнях управління для досягнення якісного результату медичного обслуговування населення. Пріоритетним напрямом реалізації цього має бути конкретизація нормативно-правових актів, що, з одного боку, чітко окреслюють повноваження суб' єкта у сфері охорони здоров'я, а 3 іншого боку, регламентують взаємодію 3 іншими органами державної влади, забезпечують їх узгодженість і дуальність, усувають прогалини в законодавстві.

Висновки. Побудова дієвої, прозорої та ефективної системи менеджменту галузі охорони здоров'я $\epsilon$ можливою через систему заходів з удосконалення публічного адміністрування цією сферою шляхом визначення рівнів, принципів, методів та функцій управління, суб'єктів та комунікацій між ними. Пріоритетами функціонування системи мають бути запити та потреби суспільства на якісну та доступну медицину через впровадження поетапних мети та завдань реформи охорони здоров'я.

\section{Список літератури:}

1. Конституція України : прийнята на п’ятій сесії Верховної Ради України 28 червня 1996 р. Київ : Просвіта, 1996.80 с.

2. Державне управління охороною здоров’я в Україні: генеза і перспективи розвитку : колективна монографія / за заг. ред. М.М. Білинської, Я.Ф. Радиша. Київ, 2013. С. 14.

3. Дорошенко О.О., Шевченко М.В. Аналіз міжнародного досвіду фінансування вторинної медичної допомоги. Економіка і право охорони здоров’я. 2017. № 1(5). C. 148-155. URL://nbuv.gov.ua/UJRN/eprozd_2017_1_5 (дата 3вернення: 25.08.2020)

4. Шегедин Я.Ю. Державна політика в галузі медсестринства: структурно-функціональний аспект. Науковий вісник "Демократичне врядування». 2017. Вип. 18/19. URL: http://vivacademy.com/vidavnitstvo_1/visnyk18_19/fail/ Shegedyn.pdf (дата звернення: 26.08.2020).

5. Державна політика у сфері охорони здоров’я : колективна монографія : у 2 ч. / упоряд. Я.Ф. Радиш ; за заг. ред. М.М. Білинської, Я.Ф. Радиша. Київ : НАДУ, 2013. Ч. 1. 396 с.

6. Радиш Я.Ф. Державне управління охороною здоров'я в Україні: генезис та тенденції розвитку : автореф. дис. ... докт. наук із держ. упр. : спец. 25.00.01. Київ, 2003. 32 с.

7. Ткачова Н.М. Напрями реформування державної політики в сфері охорони здоров'я. Інвестиції: практика та досвід. 2018. № 8. С. 83-86.

8. Національна стратегія реформування системи охорони здоров'я в Україні на період 2015-2020 років. URL: http://healthsag.org.ua/strategiya (дата звернення: 26.08.2020).

9. Корольчук О.Л. Коммуникация - стратегическое направление государственного регулирования охраны репродуктивного здоровья. Держава та регіони. 2012. № 3(39). С. 52-55.

10. Муляр Г.В. Особливості взаємодії управлінських органів у сфері охорони здоров'я. Актуальні проблеми вітчизняної юриспрудениії. 2020. № 2. С. 97-100.

\section{References:}

1. Konstytutsiya Ukrayiny: pryynyata na pyatiy sesiyi Verkhovnoyi Rady Ukrayiny (1996) [Constitution of Ukraine: adopted at the fifth session of the Verkhovna Rada of Ukraine]. Kyiv: Prosvita, pp. 80.

2. Bilyns'koyi M.M., Radysha Ya.F. (2013) Derzhavne upravlinnya okhoronoyu zdoroya v Ukrayini: geneza i perspektyvy rozvytku: kol. monohrafiya [Public administration of health care in Ukraine: genesis and prospects of development: col. monograph]. Kyiv, p. 14.

3. Doroshenko O.O., Shevchenko M.V. (2017) Analiz mizhnarodnoho dosvidu finansuvannya vtorynnoyi medychnoyi dopomohy [Analysis of international experience in financing secondary health care]. Ekonomika i pravo okhorony zdorov'ya [Economics and health law], vol. 1(5), pp. 148-155. Available at: http://nbuv.gov.ua/UJRN/eprozd_2017_1_5 (accessed 25 August 2020).

4. Shehedyn Ya.Yu. (2017) Derzhavna polityka v haluzi medsestrynstva: strukturno-funktsional'nyy aspekt [State policy in the field of nursing: structural and functional aspect]. Naukovyy visnyk "Demokratychne vryaduvannya" [Scientific Bulletin "Democratic Governance"], vol. 18/19. Available at: http://vivacademy.com/vidavnitstvo_1/visnyk18_19/fail/Shegedyn.pdf (accessed 26 August 2020). 
5. Bilynskoyi M.M., Radysha Ya.F. (2013) Derzhavna polityka u sferi okhorony zdoroya: kol. monohrafiya u 2 ch. [State policy in the field of health care: collective monograph in 2 parts]. Kyyiv: NADU, p. 1, pp. 396.

6. Radysh Ya.F. (2003) Derzhavne upravlinnya okhoronoyu zdorov'ya v Ukrayini: henezys ta tendentsiyi rozvytku [Public administration of health care in Ukraine: genesis and development trends]: avtoref. dys. ... dokt. nauk iz derzh. upr.: 25.00.01. Kyiv, p. 32.

7. Tkachova N.M. (2018) Napryamy reformuvannya derzhavnoyi polityky v sferi okhorony zdorov'ya [Directions for reforming public health policy]. Investytsiyi: praktyka ta dosvid [Investments: practice and experience], vol. 8, pp. 83-86.

8. Natsionalna stratehiya reformuvannya systemy okhorony zdoroya $v$ Ukrayini na period 2015-2020 rokiv [National strategy for reforming the health care system in Ukraine for the period 2015-2020]. Available at: http://healthsag.org.ua/ strategiya (accessed 26 August 2020).

9. Korol'chuk O.L. (2012) Kommunikatsiya - strategicheskoye napravleniye gosudarstvennogo regulirovaniya okhrany reproduktivnogo zdorov'ya [Communication is a strategic direction of state regulation of reproductive health protection]. Derzhava ta regioni [The state of the region], vol. 3(39), pp. 52-55.

10. Mulyar H.V. (2020) Osoblyvosti vzayemodiyi upravlinskykh orhaniv u sferi okhorony zdorov'ya [Peculiarities of interaction of administrative bodies in the field of health care]. Aktual'ni problemy vitchyznyanoyi yurysprudentsiyi [Actual problems of domestic jurisprudence], vol. 2, pp. 97-100.

\section{СИСТЕМНО-ФУНКЦИОНАЛЬНАЯ МОДЕЛЬ ПУБЛИЧНОГО АДМИНИСТРИРОВАНИЯ РЕФОРМИРОВАНИЯ ОТРАСЛИ ЗДРАВООХРАНЕНИЯ}

Современная Украина находится в активном движении, которое осуществляется путем разработки и воплощения реформ в различные отрасли. Одной из главных реформ, от которой зависит демографический, социальный и экономический потенцииал общества, является реформа сферы здравоохранения. В соответствии с законодательством Украины, здравоохранение является одним из приоритетных направлений государственной деятельности и имеет свои особенности. В статье осуществлен общий анализ государственной политики в сфере здравоохранения, который позволил осуществить ее обоснование с позиции системного и функционального подходов. Определень особенности, содержание и направления администрирования реформь отрасли здравоохранения Украины, которое требует немедленной разработки организационных, управленческих, политико-правовых основ. Предложено схематическое отображение модели системно-функционального подхода к публичному администрированию прочесса реформирования отрасли.

Ключевые слова: государственная политика, администрирование, реформирование, система здравоохранения, системно-функциональный анализ.

\section{PUBLIC ADMINISTRATION OF HEALTH CARE REFORM SYSTEMIC AND FUNCTIONAL MODEL}

Modern Ukraine is nowadays in active movement, which is carried out by the development and implementation of various industries' reforms. One of the most basic, which determines demographic, social and economic potential of society, is a health care reform. The State Administration of Health Care Activity has its own peculiarities. According to the legislation of Ukraine, health care is one of the priority directions of state activity. The article carries out a general analysis of the state health policy, which allowed its justification from a position of systemic and functional approaches. Thus, separate issues of status, competence and interaction of bodies that carry out state policy and management activities in the field of healthcare in Ukraine are considered. The main powers of government branches - legislative, executive and judicial, as well as local self-government bodies, resulting in defined forms and limits of their interaction, are disclosed in the article. The publication focuses on system connections, as well as main actors of these communications are named. The main problems of the industry are defined - low level of financial and material support, technically obsolete infrastructure, imperfect management, lack of proper motivation of personnel system, high level of corruption in all spheres and links of the health care system, etc. The peculiarities, content and directions of Ukrainian health care reform administration are outlined, which require immediate development of organizational, management, political and legal principles. A schematic reflection of the model of systematic and functional approach to public administration of industry reform process is proposed. It is concluded that the system of management and organizational mechanisms in the field of health care should act in a coordination among the entities, holistically and balanced at all levels of government to achieve a quality result of health care. The priorities of the system functioning should be society's demands and needs for quality and affordable medicine through implementation of phased goals and tasks of the health care reform.

Key words: state policy, administration, reform, health care system, system-functional analysis. 